\title{
Civilizational evolution of financial system progressive development mechanisms
}

\author{
Borsch Lyudmila Mihaylovna \\ V.I. Vernadsky Crimean Federal University \\ Vernadskogo Avenue, Simferopol, \\ Republic of Crimea, Russia, 295007 \\ 1-borsh49@mail.ru \\ Vorobyov Yuriy Nikolayevich \\ V.I. Vernadsky Crimean Federal University \\ Vernadskogo Avenue, Simferopol, \\ Republic of Crimea, Russia, 295007 \\ vorobyov_120758@mail.ru
}

\author{
Vorobyova Elena Ivanovna \\ V.I. Vernadsky Crimean Federal University \\ Vernadskogo Avenue, Simferopol, \\ Republic of Crimea, Russia, 295007 \\ vorobyova_110760@mail.ru \\ Burkaltseva Diana Dmitrievna \\ V.I. Vernadsky Crimean Federal University \\ Vernadskogo Avenue, Simferopol, \\ Republic of Crimea, Russia, 295007 \\ di_a@mail.ru
}

\author{
Zotova Snezhana Anatolyevna \\ V.I. Vernadsky Crimean Federal University \\ Vernadskogo Avenue, Simferopol, \\ Republic of Crimea, Russia, 295007 \\ snega_4@mail.ru
}

\begin{abstract}
The research objective is the study of the existing mechanisms of the contemporary financial system and its markets. The general scientific research, the comparative, technical and economic analysis and the expert assessments methods were applied to solve the research tasks. The research reveals the most topical policy priorities of the financial system and its markets development. The article defined the consolidating functions of state regulation aimed at balance correction including the function of demand and supply adapting. It is the financial system where the financial resources are formed at the micro level and the centralized state funds are formed at the macro level. Thus, the state distributes monetary funds through financial instruments, forming budgets of all levels and extra-budgetary funds. Highlighting the priority of any given macroeconomic and institutional theories, the contemporary financial system is studied as a complex and dynamic mechanism that ensures different interests and determines approaches for tasks solving at each specific historical level. The article generalized the information that determines the classification of the financial system and the progressive development of modern financial markets, identifying their organizational and regulatory principles for the financial system modernization. A multiple excess of the financial market over the scale of the economy real sector was investigated and determined. The reasons for the rapid development of financial circulation have not been completely explored yet: financial markets arise at a certain stage of the market relations development, when the state has the opportunity to play a crucial role in market processes and in the financial system. The development of the financial system and financial markets, their functioning as an independent system on the basis of their own principles is enormously influenced by the state policy. The paper discloses the functions of the financial system in the circulation of monetary resources, which must be
\end{abstract}

sufficient - more than necessary for servicing the needs of commodity production and trade. The article analyzes and reveals the beginning of the financial operations rapid development and the transition to financial-unsecured money that occur not by an accidental circumstance but connected with time and these actions - with cause-and-effect relations as well. Only a sufficient amount of money in circulation can ensure the amount of free money supply that can circulate in financial transactions that are not related directly to the purchase and sale of goods and services. Evolutionary processes provide an opportunity to assert that the financial system and financial markets did not simply originate in the process of market mechanisms evolution but arose solely due to the issuing activity of the state, which in turn finds support in the nature of contemporary money.

Keywords-mechanisms, evolution, financial system, financial markets, financial resources, consolidation, financial transformation, institutes, state regulation.

\section{INTRODUCTION}

The present financial system and its evolution of the progressive development mechanisms are based on the disclosure of the financial system macroeconomic essence towards modernization. The given direction of development requires the disclosure of the methodological problems corresponding range. It is necessary to determine and record a historical retrospective and the starting points of the research direction. Modern scientific theory can make demands on the objectivity of the methodology interpretation, if it is based on the consistency methodology, took all the rational that was 
inherent in its early development stages. It is as well necessary to determine the most relevant priorities for the development policy of the financial system and financial markets as well as the budget system.

The aim of the research is to study the existing mechanisms evolution of the contemporary financial system and its markets.

To achieve the goal, it is necessary to solve the following tasks: to define the conceptual foundations of the financial system and its markets; to analyze the regulatory mechanisms of financial markets and identify their evolution; to study the state regulation of the Russian financial system as the main progressive consolidator of financial resources and a cash flow regulator.

\section{Materials and Methods.}

The methodological and theoretical basis of the research is the provisions of scientific theories of the financial system and financial markets. In the research process such scientific methods were used, among which the statistical, historical, visual and economic analysis methods are important. The method of sociological research was used for more detailed and comprehensive analysis, as well as for studying the research object - the disclosure of the macroeconomic essence of the financial system and financial markets towards the financial economics modernization. The comparisons method was used to identify GDP growth rates in the G-7 countries. Methodological approaches were used to determine the essence of financial capital in the financial system during studying the financial sector development. A structural and functional approach was applied during studying the financial system and financial markets, objectively assessing the macroeconomic functioning through the mechanism of state policy. The system approach was used when determining the balance of the financial system, financial market and budgetary sphere. The statistic method was applied when determining GDP per capita. Factor analysis was used to identify the main factors influencing the development of the financial system and the financial market. While researching the general scientific methods of scientific abstraction, historicity, logic, induction and deduction were used in determining the essence of the financial market, financial system of progressive development.

\section{RESULTS AND DISCUSSION}

\section{Conceptual foundations of financial system and financial markets}

Disclosure of the macroeconomic essence of financial markets towards the modernization of the financial system and its development requires disclosure of the methodological problems of the corresponding range. First, it is necessary to determine and record a historical retrospective and the starting points for the progressive direction of the financial system research. Modern scientific theory can make demands on the objectivity of the methodology interpretation, if it is based on the consistency methodology, took all the rational that was inherent in its early stages of development. Secondly, it is very important to determine the most topical priorities of the progressive development policy of the financial system and financial markets and to identify the main consolidating functions of state regulation. It is necessary as well to determine the criteria for selecting the modern instruments of influence, to identify corrective mechanisms for implementing practical policy in the financial system. Thirdly, it is important not to limit the "space of freedom" due to which happens the timely regulation of the priority of certain macroeconomic and institutional theories based on the methodological aspects of historical and temporal origin.

The modern financial system is a complex and dynamic mechanism that ensures different interests and determines approaches for tasks solving at each particular historical stage, when rather dynamic approaches can distort the balance. This given imbalance can spread very quickly throughout the entire financial system, it is this impetus that can become a tangible factor of the supply and demand equilibrium in the financial market.

This specific direction related to the financial economy and the financial markets evolution was studied long and hard by analysts. Their works reflected the modern scientific generalizations that determine the financial economy classification of modern financial markets, their organizational and regulatory principles, and the modernization strategy that can conceptually coordinate the positions when forming the essential characteristics of financial markets. The importance of the financial systems role in the modern economies development is reflected in their writings [1-23].

The financial system and its structure objectively require a structural-functional approach (that is, macroeconomic) implemented through the mechanism of state policy. Nobel Prize winner Gerry Becker considered that the market equilibrium and stability of priorities implemented consistently and constantly, form the core of the macroeconomic approach [6]. These are the exact foundations that form a basic model for determining the available financial resource potential. Taking into account the processes of global globalization, integration of the economy and state policy, the modernization of production sectors and the transition of the Russian economy to the forecasting and planning system, the macroeconomic core approach is being formed, that is highlighted in the Development Strategies of Russia up to 2030. This given classical methodology should implement a deep and systemic transformational reset, and the integration of not only the economy, but necessary improvement of the tools and mechanisms of the financial system, including the process of theoretical regularities with eliminating the time mistakes [20].

The financial system is based on financial markets operating in real time, namely: monetary, issuing, financial services market, foreign exchange, securities market, debt market, stock market, forex market, speculative market and others. In functional areas these different types of financial system can be called the segment markets. Financial markets are polysystemic segments since they contain a discrete set of weighty conglomerates, common attributive phenomena and processes. 
Thus, financial markets constitute a set of financial system autonomous segments, within which a wide range of financial legal relations is constantly exercised resulting in expanded reproduction of financial (monetary, foreign exchange, debt, credit) flows that ensure the dynamic development of the national economy and strengthen the state participation in the globalization processes.

Regulatory policy of the financial system should be the universalization of state controlling and regulating institutions. The creation of financial universalization in the financial system should be reflected in the system policy and a set of interrelated methods and mechanisms by which the tendencies of departmental isolation are neutralized and the interaction between such state regulators as Sberbank of Russia, the Ministry of Finance and the State Commission for Regulation the Financial Markets is enhanced. The development of the financial system demonstrates a new paradigm for the development of both world and national economies. At the same time, the national approaches, applied in the financial system implemented at this time, are not yet a complement to international approaches and preferences. The financial system is a kind of financial markets, which are also market segments. The financial economics segments are a system linked in a straight and interconnected way, where the flowing of financial capital and the financial assets redistribution will happen.

The financial system and financial markets form the basis of the economy macroeconomic development, where the key principle of the state regulatory function should be the universalization of controlling and regulating institutions, expressed in the system policy and in a set of interrelated methods and mechanisms, by which the tendencies of departmental isolation are neutralized and interaction between state regulators is activated.

\section{Regulating mechanisms of the financial system and its evolution processes}

The conception regarding the state role in implementing an effective policy for the financial markets functioning was not defined in national economic theory during the functioning of the financial system and its markets. It is the state that acts as the main consolidator of the financial system and comprehensively defines the format for the individual interests' realization. The state policy is systematically strengthening the national interests in the basic segments of the financial system; the progressive development vector of the national economy as a whole depends on its role and functions [25].

Throughout the evolutionary process of developing the financial system and financial markets, in particular, the problem of the correlation between directness and selfregulation of direct institutional regulation methods and not direct but the systemic perception of psychology on the financial markets diversity as well is constantly reproduced [17].

The liberals' policy comes down to the fact that the market mechanism under normal conditions is able to ensure independently the smooth operation of the financial system.
The state should take part when the external forces may threaten the market mechanism of the financial system to outbalance [22].

Increasingly, the scientific schools consideration goes to the arising question as to what state policy should be, so that the self-regulating system would not outbalance. In our opinion, at the present level of development the financial system and its internal self-regulation mechanisms are imperfect in the market system. At this interval the state regulation performs consolidating functions and acts as a regulator of the organic component of this functioning.

Even in the US, the state controls the entire financial system and financial processes through direct participation (GNMA government, SBA, Farmer Mac I Federal Home Loan Banks), it controls the largest commercial organizations on the market (financial guarantors FNMA, FHLMC). Congress and the US government can influence the state of affairs in almost all markets, where structured products circle around [19].

An important role is played by non-governmental guarantee companies that work in the securities market (MBIA, AMBAC, FGIC, FSA, Radian), as well as the company of individual loans and mortgages (MGIC, UGS, PMI) [5]. It results in the fact that the US and European economics operate trouble-free. In the twentieth century the entire west economics was based on the active application of the Keynesian ideas of stimulating the economy by the state in the postwar years. The G-7 countries had a significant GDP growth after the Second World War (Figure 1).

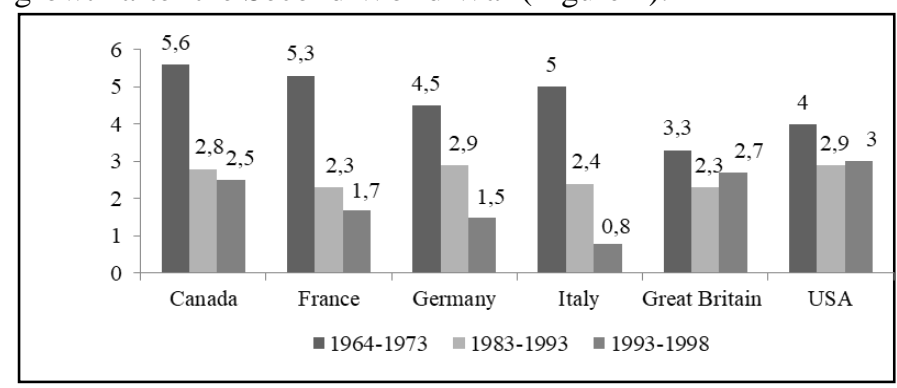

Composed by [7]

Fig. 1. GDP growth rates in G-7 countries, \% per year

After the application of expansion in the monetary policy of the 55-65-ies in many countries the inflation was approaching which did not cause concerns amid high economic growth rates. The idea of building a society with "universal well-being and prosperity" appears as a consequence of the economic turnover saturation with the money supply. This society was planned to provide workers and employees with a decent salary in order to ensure a high total effective demand for the sale of developing industry, agriculture, and services.

At the same time, the full commodity-money circulation releases the temporarily surplus funds, which constitute the ground for increasing the volumes of the financial system and its financial markets, which were strictly controlled by the state in the post-war period. Only in the last 25 years of the XX century, their rapid development began and reached the full advantage of financial turnover over the real sector of the 
economics. In 1970 the global volume of the bond market was about \$1 trillion, in 1980 this index amounted to \$2 trillion, in 1990 - \$12 trillion, in 1995 the state index was already over $\$ 20$ trillion and at the end of the century was more than 25 trillion USD per year [7].

Since, by that time the market began to be saturated, the expansion of the money supply led to the filling of financial markets with the money supply, the understanding of serving the interests of the economy real sector disappeared in the financial markets. This period was defined as the state control weakening of Western and European countries. This gave a powerful impetus for the development of new, unknown until that day, financial instruments and the financial sector as a whole [3]. The processes of reducing control over financial markets began with the United States. Later, under the influence of lobbyists and Senator Gramm, another law was adopted - Commodity Futures Modernization CT, which virtually annulled the regulation of the derivative securities turnover. Control over these securities was assigned to an agency completely unknown to the Federal Assembly, which had no specialized professionals, according to the assessment of professional researchers. Each of the attenuations did not seem significant and could not lead to failure. These were the insignificant steps that opened the way for a systemic financial crisis. Only the summit of the "Big Twenty" revealed its reasons, one of which was the removal of the state from regulation and control over financial markets.

Given there is time transience and relying on objective statistics of relatively successful states, we shall demonstrate the dynamics of development and growth of financial resources expressed in GDP per capita (Table 1).

TABLE I. GDP PER CAPITA AS PPP (IN POST INTER DOLLAR IN 2005)

\begin{tabular}{|c|c|c|c|c|c|c|c|}
\hline & Russia & Ukraine & Japan & Turkmenistan & USA & Kazakhstan & Turkey \\
\hline 2001 & 14829 & 5291 & 33927 & 5292 & 45978 & 11314 & 12842 \\
\hline 2002 & 15604 & 5622 & 33889 & 5622 & 46367 & 12423 & 13468 \\
\hline 2003 & 16817 & 6201 & 34333 & 5889 & 47360 & 15423 & 14020 \\
\hline 2004 & 18098 & 7004 & 35078 & 5808 & 48597 & 15532 & 14728 \\
\hline 2005 & 19325 & 7246 & 35658 & 6495 & 49762 & 14729 & 16309 \\
\hline 2006 & 20970 & 7828 & 36142 & 7125 & 50599 & 16014 & 17250 \\
\hline 2007 & 22799 & 8497 & 36697 & 7815 & 51011 & 17541 & 17901 \\
\hline 2008 & 24006 & 8739 & 36278 & 8844 & 50384 & 18855 & 17836 \\
\hline 2009 & 22122 & 7479 & 34317 & 9249 & 48558 & 19996 & 16783 \\
\hline 2010 & 23108 & 7824 & 35750 & 9942 & 49373 & 20096 & 17959 \\
\hline 2011 & 24074 & 8281 & 35775 & 11213 & 49791 & 21987 & 19660 \\
\hline 2012 & 24880 & 8322 & 36368 & 12235 & 50520 & 22973 & 20220 \\
\hline 2013 & 24879 & 8339 & 37149 & 13236 & 51008 & 23586 & 21650 \\
\hline 2014 & 25144 & 8243 & 37333 & 14332 & 51830 & 23522 & 22401 \\
\hline 2015 & 24880 & 7465 & 37818 & 14992 & 52790 & 23420 & 23382 \\
\hline 2016 & 24124 & 7321 & 38240 & 15648 & 53273 & 23310 & 23679 \\
\hline 2017 & 24026 & 7115 & 38239 & 16807 & 53915 & 23419 & 23957 \\
\hline
\end{tabular}

State regulation of this market segment absolutely affects the interests of virtually all population segments. Analytics indicate that money has turned from a tool of economic activity into one of the human reality measurement of "triumph" or a feeling of "existence".

The multiple progressive excess of the financial market over the scale of the economy real sector is well known; nevertheless the reasons for the financial circulation rapid development have not been completely explored yet. Financial markets arise at a certain stage in the market relations development, when the state has the opportunity to play an important role in market processes, and in the financial sphere - a crucial for the financial markets to exist and function as an independent system based on their own principles. The money resources in circulation must be in sufficient quantity, more than necessary to serve the needs for commodity production and trade. The beginning of the rapid development of financial transactions and the transition to financially unsecured money are not accidental circumstances in time, but the actions related to cause-effect relationships. Only a sufficient amount of money in circulation can ensure a sufficient amount of free money supply, which can circulate in financial transactions not related directly to the purchase and sale of goods and services. [27]

Evolution processes provide the opportunity to assert that financial markets were not simply originated in the process of market mechanisms evolution, but arose solely due to the state emission activity, which in its turn finds support in the nature of modern money. In our opinion, the adoption of such explanation is determined by the theses on the state decisive role not only in historical origin, but also in the functioning of the financial system and modern financial markets. This requires a revision of the state influence mechanisms on the ongoing financial processes - from external regulation to direct regulation of the financial system and financial markets reducing the risks level [21].

The hierarchy of the state influence directions on the financial markets functioning has the following form: monetary and currency policy; regulating and controlling activity in relation to the creation and operation of financial institutions; direct impact on the financial system through the mechanism of taxes and other mandatory contributions to centralized resources and funds; direct participation in the financial system functioning as a source of financial resources and their consumers.

\section{State regulation of the Russian financial market}

The supply of financial markets with financial resources is not singled out as a separate research subject; especially from the point of analyzing this process as the most important regulatory function of the state. The financial market consists of the reproduction processes functions, the accumulation and redistribution mechanisms, the economic and legal relations system and the investment function. 
Let us consider the main consolidating functions of state regulation (Figure 2).

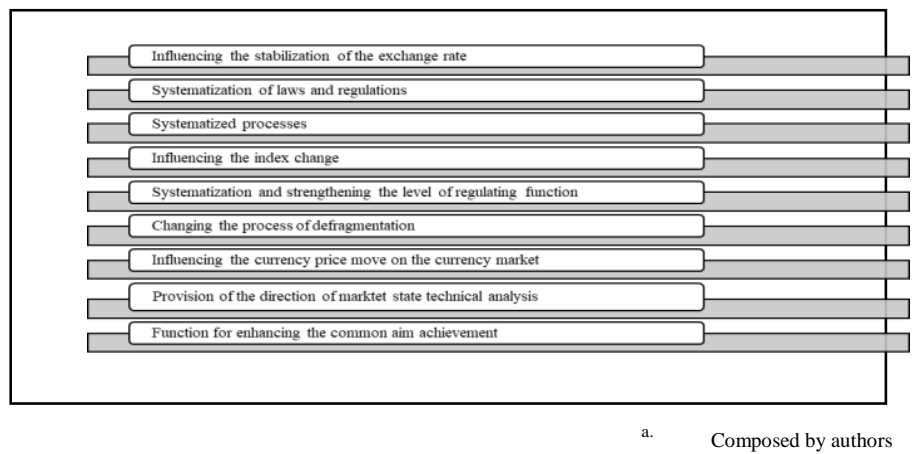

Fig. 2. Basic consolidating functions of the state regulation

It is the consolidating functions of state regulation that are aimed at eliminating the imbalance including the function of demand and supply balancing.

This tendency acquires a fundamental character, defining new features and parameters in a consistent progressive system of controlling financial markets. At the same time the entering into a qualitatively new period of systemic transformations testifies not only the consolidation of the constructive format of the economy innovative development, but also the formation of financial markets, the perception of a completely new type of reality on other methodological bases, principles and priorities.

Given the official data of the Central Bank of the Russian Federation, the money supply for the M2 aggregate (national definition) is 41598 billion as of 01.02.2018. Let us consider this figure in the structure (Table 2).

TABLE II. THE STRUCTURE OF MONEY SUPPLY M2 AS ON 01.02.2018

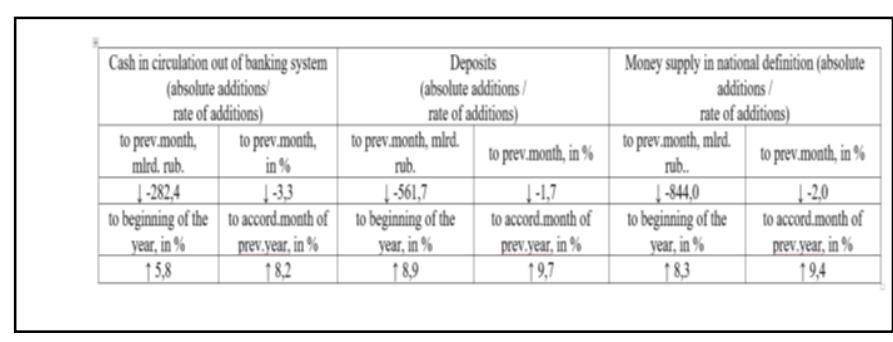

Composed by [24]

Let us study the dynamics of the money supply M2 (contributions of various components in the annual growth rate) as of 01.02.2018 (Figure 3).

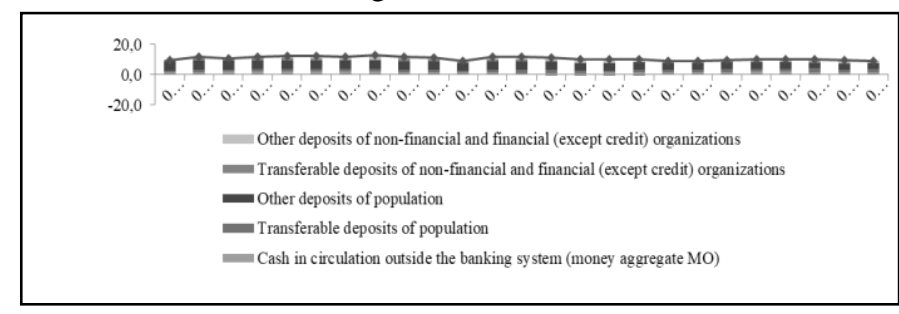

Composed by [24]
Dynamics of money supply M2 (contributions of various components in annual growth rate)

One of the important components of the financial market development and functioning are monthly reserves such as: international, currency, foreign exchange including the SDR account, reserve position in the IMF, monetary gold. These figures are presented in table 3 .

Basing on Table 3 the following conclusions can be drawn: during the period from 2005 to 2018 there was an increase in all items: monetary gold - 21.62 times; the IMF reserve position -909.3 times; accounts in SDRs - almost 3494 times; foreign exchange as a reserve -2.8 times; currency reserves 2.85 times; international reserves - 3.38 times.

The data in Table 3 show that state regulation responds to the financial market in a timely manner and applies the necessary tools to increase gold and foreign exchange reserves, the balance of the financial system is observed which positively affects the development of the economy real sector.

TABLE III. MONTHLY FIGURES PER 2005-2018, USD MLN

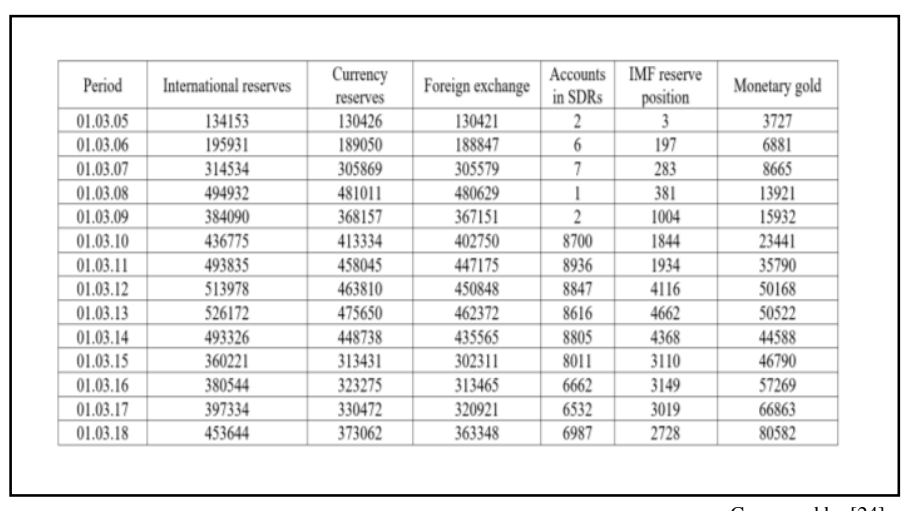

The world processes of globalization are making their own adjustments, and the prospects likelihood of the combining national and world money through the mechanism of new mobile money surrogates (almost money) is a process that is not legalized in the banking system. Self-legalization of money surrogates occurs through exclusive emission mechanisms that are not guaranteed by the state. More often the introduction of money surrogates occurs through the clearing companies; this ensures the organization of clearing settlements in more modern schemes. The renewed paradigm of macroeconomic orientation certainly creates new opportunities for modern modifications in monetary and financial relations. As mentioned earlier, it is this sphere that experiences the rapid and profound revolution in the previous decades. This testifies to the existence of a communicative convergent market that with respect to the monetary and financial system is a feature of the formation of a "symbol symbolic exchange market and hence new monetary origins". Electronic money is a tool and a factor in increasing money emission, potentially affecting its volumes, while simultaneously providing an unprecedented increase in the speed of the money turnover, resulting in strengthening 
financial and exchange operations, and thus improving the regulatory conditions to ensure the financial markets with financial resources in the current reality.

Globalization "generates processes directly opposite to the physical economy, because it has its own information aspects of sensitivity and its own powerful essence" [4].

Restoring an order in the ownership of gold and currency reserves and exercising state control over their accumulation and use provides an opportunity to significantly expand the functions of these reserves and turn them into a source of the state economic development. Figure 4 shows ten countries with the largest gold reserve.

The acquaintance with the real state of the gold and foreign currency reserves testifies to the correctness of the thought that they carry a smoothing element for fluctuations in the balance solvency. The largest accumulations of reserves were grouped in those countries which have no problems with the balancing of currency earnings and costs. Together, these countries hold half of the world's gold and currency reserves

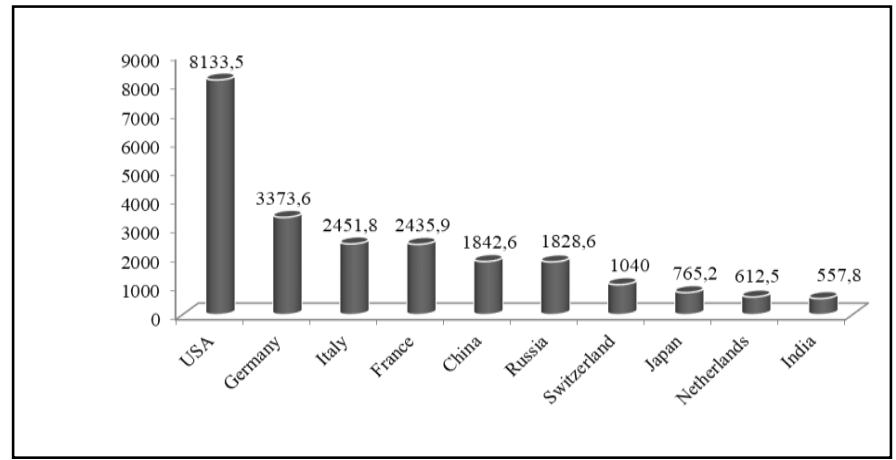

Composed by [25].

Fig. 3. Ten countries with largest gold reserve (December 2017), tons

Financial markets of Russia form a self-sufficient financial system that operates under the real time laws, according to a certain trajectory and speed. These laws form the newest kinetic economic and financial system structure. We are faced with identifying many of its unknowns in order to see and realize the depth of its development transformational principles.

The hierarchy of the state influence directions on the functioning of financial markets has the following form: monetary and currency policy; regulating and controlling activity relating to the creation and operation of financial institutions; direct impact on the financial system through the mechanism of taxes and other mandatory contributions to centralized resources and funds; direct participation in the financial system operation as a source of financial resources and their consumers.

The financial system and financial markets form the basis of the economy macroeconomic development, and the key principle of the state regulatory function should be the universalization of controlling and regulating institutions expressed in the system policy and a set of interrelated methods and mechanisms, by which the tendencies of departmental isolation are neutralized and interaction between state regulators is activated.

\section{CONCLUSION}

The financial system demonstrates new paradigms for the national economy development. At the same time the realized national approaches are yet an organic complement to international approaches and prerogatives.

The financial system segments are a system where the flowing of financial capital and the redistribution of financial assets occurs.

The hierarchy of institutions and their policies are aimed at the functioning of the financial system and its financial markets. It has the following form: monetary and foreign exchange policy; direct participation in the activities of the financial market as sources of financial resources and their consumers; direct impact on financial activities through taxes and other mandatory payments to centralized resources and funds; regulatory and supervisory activity related to the creation and operation of financial institutions.

The budget of Russia plays a key role in the financial market development and acts as an effective regulator. Because it is through the state, regional, municipal budgets and other centralized monetary funds that centralization of money is carried out.

Decentralized and centralized money funds form a budget provides a possibility to maneuver them, concentrate them on the most important sectors of economic and social development and implement an integral financial and economic policy in the state territory.

Further research should be directed to the study of budget priorities resource provision, as the most important state regulation function of the financial system, as well as to the theoretical and methodological generalizations of the institutional and global mechanisms of the financial system.

\section{References}

[1] L.M. Borsch, D.D. Burkaltseva, Y.N.Vorobyov, E.I. Vorobyova, and V.V. Chepurko. "Dichotomy or unification of contrasts of the market and capitalism: Forecast and plan (part 1)", International Journal of Economic Research, no. 13 (9), pp. 3775-3787, 2016

[2] D. Burkaltseva, Yu. Vorobyov, L. Borsh, S. Gerasimova, and Chepurko V. "Structural modelling the system of ensuring the economic security of the complex territorial socio-economic system of the eurasec", International Journal of Applied Business and Economic Research, Vol. 14, no. 9, pp. 5683-5704, 2016.

[3] R. Rajan, L. Zingales. "The great reversals:the politics of financial development in the 20th centry", Journal of Financial Economics, Elsevier, Vol. 69 (1), pp. 5-50, 2003

[4] J. Stiglitz. "Monopoly, Not-Linear Pricing, and Imperefect Information The Insurance Market”, Review of Economic Studies, Vol. 44, no. 3, pp. 407, 1997.

[5] I. Aksenov "Stages of development of securitization in the USA: 1930 2008". URL: http://www.rusipoteka.ru/files/articles/2008/aksenov-1.pdf. 
[6] G. Becker. "Economic analysis and human behavior", THESIS, Release 1, pp. 27, 1993.

[7] N. Beams. "The world economic crisis - 1991-2001, Part 1." URL: http://wsws.org/ru/2002/apr2002/ecol-a12.shtml

[8] N. Simchenko, S. Tsohla, "Revisiting the issue of the place of economic experiment in the study of the economic dynamics cyclicity", Journal of Advanced Research in Law and Economics, vol.VII, no. 6(20), Fall 2016, pp.1485-1493, 2016.

[9] N.G.Vovchenko, O.B. Ivanova, E.D. Kostoglodova, T.F. Romanova. "Institutional aspekts of provision of sustainability of budget system of the Russian Federation", Asian Social Science, v. 11, no. 20, pp. 235243, 2015.

[10] O.M. Korobeynikova, D.A. Korobeynikov, L.V. Popova, O.V. Savina, R.Sh. Kamilova. "The current state of the payment infrastructure and development of payment systems in Russia and the Volgograd region", Revista ESPACIOS, Volume 38, Issue 62, 2017.

[11] V.V. Pshenichnikov, A.V. Babkin, "Digital money as a product of the development of information and telecommunication technologies", Quality Management, Transport and Information Security, Information Technologies, pp. 259-265, 2017.

[12] M.Yu. Kussy "Financial risks and financial security of the enterprise", Scientific Bulletin: Finance, Banks, Investments, no. 4 (23), pp. 35-40, 2013.

[13] A.P. Bondar. "State support of financial security of enterprises in the sphere of housing construction", Scientific bulletin: finances, banks, investments, vol. 14, pp. 13-15, 2012.

[14] A.P. Bondar. "Providing economic security of regions in Ukraine", Scientific bulletin: finances, banks, investments, vol. 4 (23), pp. 94-99, 2013.

[15] Z. Varnaliy, S. Onishchenko, A. Masliy "Threat prevention mechanisms of Ukraine's economic security”, Economic Annals-XXI, T. 159, no. 56, pp. 20-24, 2016.
[16] M.N. Dudin, "Public and business regulation as the basis of selforganization and evolution of the national innovation system", The Journal of Internet Banking and Commerce, vol. 21, no. S4, July 2016.

[17] V. Klinov, "What should be the economic policy (On the book of E. Reinert "How rich countries became rich, and why poor countries remain poor")", Questions of economics, vol. 1, pp. 142-150, 2012.

[18] Yu. Olsevich, "Market psychology and economic power (on the psychological approach of A. Greenspan to the analysis of economic problems)", Issues of economics, vol. 4, pp. 99-118, 2012.

[19] N. Simchenko, S. Tsohla, I. Podsmashnaya. "Application of the analytic hierarchy process to structure the motivational expectations of the economically active population of the Republic of Crimea", Journal of Applied Economic Sciences Open Access, Vol. XI, Issue 8 (46) Winter 2016, pp. 1569-1580, 2016.

[20] D. Strauss Kahn, "Economics should be fair", URL: http://vz.ru/economy/2011/4/5/4811282.html

[21] D. Fowley, "Mathematical formalism and political economy content", Issues of economics, vol. 7, pp.87, 2012.

[22] I.Ya. Chugunov, "Budgetary system as an instrument for regulating economic development", The author's abstract of economics. Specialty 08.04.01. "Finance, money circulation and credit." Kiev: Institute of Economics and Forecasting of the National Academy of Sciences of Ukraine, 29 p., 2003.

[23] E. Yasin, "Social results of the transformation, or twenty years late", Issues of economics, vol. 8, pp. 77-96, 2011.

[24] Central Bank of the Russian Federation, URL: http://www.cbr.ru/statistics/?prtid=ms

[25] Gold and foreign currency reserves for 2017, URL: https://skupkapiter.ru/stati./zolotovalyutnyj-zapas.html

[26] Federal Treasury of the Russian Federation, URL: http://datamarts.roskazna.ru/razdely/makroekonomicheskiepokazateli/osnovnye-makroekonomicheskie-pokazateli-strang20/?paramPeriod $=2014$

[27] Indicators of world development. URL: http://qps.ru/5uM62 